5. Бакин О.В., Рогова Т.В., Ситников А.П. Сосудистые растения Татарстана. Казань, 2000. 496 с.

6. Бузунова И.О., Хапугин А.А., Агеева А.М., Варгот Е.В. Новые находки шиповников (Rosa L., Rosaceae Adans.) в Средней России // Бюл. МОИП. Отд. биол. 2012. Т. 117, вып. 6. С. 76.

7. Васюков В.М. Растения Пензенской области (конспект флоры). Пенза, 2004. 184 с.

8. Гафурова М.М. Сосудистые растения Чувашской Республики. Флора Волжского бассейна. Т. 3. Тольятти, 2014. 333 с.

9. Еленевский А.Г., Радыгина В.И., Буланый Ю.И. Конспект флоры Саратовской области. Саратов, 2008. 232 с.

10. Еленевский А.Г., Радыгина В.И., Буланый Ю.И. Определитель сосудистых растений Саратовской области (Правобережье Волги). М., 2001. 278 с.

11. Маевский П.Ф. Флора средней полосы Европейской части России. 11-е изд. М., 2014. 635 с.

12. Плаксина Т.И. Конспект флоры Волго-Уральского региона. Самара, 2001. 388 с.

13. Раков Н.С., Саксонов С.В., Сенатор С.А., Васюков В.М. Путеводитель Сосудистые растения Ульяновской области. Флора Волжского бассейна. Т. 2. Тольятти, 2014. 295 с.

\title{
THE GENUS ROSA L. (ROSACEAE) IN THE HERBARIUM INSTITUTE OF ECOLOGY OF THE VOLGA RIVER BASIN OF RUSSIAN ACADEMY OF SCIENCES (PVB)
}

(C) 2016

S.V. Saksonov, doctor of biological sciences, professor, deputy director for science, head of the Laboratory of Problems of Phytodiversity

V.M. Vasjukov, candidate of biological sciences, researcher of the Laboratory of Problems of Phytodiversity S.A. Senator, candidate of biological sciences, senior researcher of the Laboratory of Problems of Phytodiversity

N.S. Rakov, candidate of biological sciences, researcher of the Laboratory of Problems of Phytodiversity

A.V. Ivanova, candidate of biological sciences, researcher of the Laboratory of Problems of Phytodiversity Institute of Ecology of the Volga River Basin of Russian Academy of Sciences, Togliatti (Russia)

Abstract. The herbarium of the Institute of ecology of the Volga river basin of RAS, Togliatti (PVB) stores about 200 samples from 22 species of Rosa L. (Rosaceae) from 8 sections: Rosa rugosa Thunb. (section Rugosae Chrshan.), Rosa acicularis Lindl., Rosa cinnamomea L., Rosa glabrifolia C.A. Mey. ex Rupr., Rosa pratorum Sukacz., Rosa gorenkensis Besser (section Cinnamomeae DC.), Rosa canina L. s. str., Rosa corymbifera Borkh., Rosa podolica Tratt., Rosa subafzeliana Chrshan., Rosa caesia Sm., Rosa lupulina Dubovik, Rosa dumalis Bechst., Rosa uncinella Besser, Rosa subcanina (Christ) Vuk. (section Caninae DC.), Rosa villosa L., Rosa subpomifera Chrshan. (section Villosae DC.), Rosa rubiginosa L. (section Rubiginosae Desegl.), Rosa glauca Pourr. (section Glaucae Tzvelev), Rosa alba L. (секция Rosa), Rosa spinosissima L. s. str., Rosa tschatyrdagi Chrshan. (section Pimpinellifoliae DC.), collected from the Volga region, southern Urals and adjacent territories: Bashkortostan, Mordovia, Chuvash Republic, Vladimir, Volgograd, Kirov, Penza, Samara, Saratov, Tambov, Ulyanovsk, Chelyabinsk region. Rosa tschatyrdagi Chrshan. are reported in Samara region for the first time.

Keywords: Rosa, Rosaceae, Rosa tschatyrdagi, new species, herbarium, PVB, Institute of ecology of the Volga river basin of RAS, Volga region, South Uralsk, Republic of Bashkortostan, Republic of Mordovia, Chuvash Republic, Volgograd oblast, Penza region, Samara region, Saratov region, Ulyanovsk region, Chelyabinsk region.

УДК $56.017 .2+551.8: 551.782 .2(470.4)$

\section{ГЕОГРАФИЧЕСКИЕ УСЛОВИЯ И РАЗВИТИЕ РАСТИТЕЛЬНОГО ПОКРОВА СРЕДНЕГО ПОВОЛЖЬЯ В ПЛИОЦЕНЕ}

(C) 2016

С.А. Сенатор, кандидат биологических наук,

старший научный сотрудник лаборатории проблем фиторазнообразия

В.П. Моров, научный сотрудник экологического музея

Институт экологии Волжского бассейна РАН, Тольяттти (Россия)

Аннотация. Обсуждаются вопросы развития флоры на территории Среднего Поволжья в плиоцене. Предпринята попытка реконструкции географических условий и растительного покрова. Приводится краткая характеристика природных условий и ландшафтов, растительного покрова Среднего Поволжья и прилегающих территорий. 
Приводится схема сопоставления общей и региональной шкал плиоцена. Верхней границей плиоцена в настоящей работе принята верхняя граница гелазийского яруса. Плиоцен - очень неспокойный геологический век, во время которого относительно быстро происходила смена теплых и холодных этапов, каждый из которых характеризовался ландшафтно-климатическими изменениями. Преобразования ландшафтной обстановки происходили на фоне прогрессирующего похолодания климата с увеличением контрастности летних и зимних температур. Основные геоморфологические структуры Среднего Поволжья, такие как Приволжская возвышенность, Самарская Лука, Жигулевские горы, Общий Сырт, речная сеть, возникли или до начала этого периода, или в течение него. Основные растительные формации в их широком понимании (тайга, широколиственные и мелколиственные леса, степи) сложились уже к началу плиоцена. В плиоцене происходило лишь их обеднение за счет постепенного исчезновения теплолюбивых видов и приближение по составу к современным формациям. Большая часть видов к концу плиоцена приняли современный облик.

Ключевые слова: плиоцен, географические условия, климат, растительный покров, реконструкция, Среднее Поволжье, Волга, Приволжская возвышенность, Заволжье, Общий Сырт, Акчагыльское море, акчагыл, челнинская свита, сокольская свита, чистопольская свита, домашкинская свита.

Постановка проблемы. По меткому выражению известного ботаника Г.М. Зозулина [1], «...скудность фактического материала (преимущественно палеоботанического) не должна побудить исследователей сложить руки перед трудностями восстановления истории флор или растительных сообществ». Вооружившись этим положением, мы предприняли попытку реконструировать географическую обстановку и условия развития флоры в Среднем Поволжье (в границах Самарской и Ульяновской областей) в плиоцене на основе обобщения опубликованных материалов. Большую роль в деле реконструкции растительного покрова играет геоморфологический анализ [2, 3], а значит, зная историю ландшафтов, можно наметить основные черты развития растительного покрова.

Прежде чем перейти к реконструкции событий, происходивших на территории Среднего Поволжья, следует обозначить принятое в настоящей работе понимание геохронологического деления этой эпохи (соответственно, и стратиграфического деления раздела). Верхняя граница раздела неоднократно пересматривалась, а поэтому большинство материалов, особенно опубликованных до 2000-х гг., требует увязки с современными взглядами на стратиграфию периода. С другой стороны, принятие Международной комиссией по стратиграфии решения об отнесении гелазийского яруса, относящегося ранее к плиоцену, к четвертичному периоду не всегда находит сторонников [4, 5]. В настоящей работе хроностратиграфия периода дана по Г.А. Данукаловой, составившей корреляцию местных стратиграфических разрезов (свиты для Самарского, Казанского Поволжья и Прикамья) к унифицированной региональной стратиграфической схеме неогеновых отложений Южных регионов Европейской части России $[6,7]$. Принятый объем плиоцена согласуется со стратиграфической схемой неогена юга России, составленной под руководством Н.Я. Жидовинова для Прикаспийского региона [8], и работами казанских специалистов [9, $10,11]$. Гелазий было решено рассматривать в составе плиоцена, что аргументированно изложено в работе Ю.Б. Гладенкова [5].

Обсуждение результатов. К началу плиоцена уже произошли коренные изменения ландшафтно-климатической обстановки, связанные с активизацией тектонических движений и общим воздыманием Кавказа, что привело к расширению суши в Северном Прикаспии и оживлению денудационных процессов [12]. В раннем плиоцене на большей части юго-востока Русской плиты преобладали континентальные условия, чему предшествовало резкое и сильное падение уровня моря в Восточном Паратетисе, что предопределило специфические особенности палеогеографического развития региона [8]. В это время активно формируется древняя гидрографическая сеть, наиболее крупной водной артерией региона является палео-Волга. Предположительно, основные черты бассейна Средней Волги, вне территории последнего оледенения, сохранились, по меньшей мере, с конца третичного периода, т.е. с плиоцена [2].

Таблица 1 - Схема сопоставления общей и региональной шкал плиоцена (по: $[4,6,7])$

\begin{tabular}{|c|c|c|c|c|c|c|}
\hline $\begin{array}{c}\text { Граница } \\
\text { ярусов, } \\
\text { млн. л. }\end{array}$ & $\begin{array}{l}\text { Сис- } \\
\text { тема }\end{array}$ & От- & $\begin{array}{c}\text { Подот- } \\
\text { дел }\end{array}$ & Ярус & $\begin{array}{l}\text { Регио- } \\
\text { ноярус }\end{array}$ & Свита \\
\hline $1,8-2,5$ & \multirow{3}{*}{ 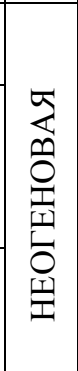 } & \multirow{3}{*}{ 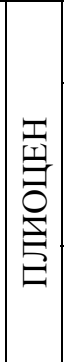 } & верхний & гелазий & \multirow[b]{2}{*}{$\begin{array}{l}\text { акчагы- } \\
\text { льский }\end{array}$} & $\begin{array}{c}\text { домаш- } \\
\text { кинская } \\
\end{array}$ \\
\hline $2,5-3,6$ & & & средний & пьяченций & & \begin{tabular}{|c|}
$\begin{array}{c}\text { чисто- } \\
\text { польская }\end{array}$ \\
соко- \\
льская
\end{tabular} \\
\hline $3,6-5,3$ & & & нижний & занклий & $\begin{array}{c}\text { кимме- } \\
\text { рийский }\end{array}$ & $\begin{array}{c}\text { челни- } \\
\text { нская }\end{array}$ \\
\hline
\end{tabular}

Возникновение в конце миоцена - начале плиоцена Жигулевской возвышенности и связанное с ним начало формирования современного рельефа Самарской Луки стали важным этапом в геологической истории региона. При этом самые ранние этапы формирования возвышенности были сопряжены с интенсивной эрозией, что обеспечивалось низким положением базиса эрозии, продолжающимся подъемом и, возможно, влажностью климата [2]. Таким образом, горный рельеф Жигулей был создан в предакчагыльское время. Г.В. Обедиентова [2] убедительно показала, что Волга текла через Жигулевские ворота уже с неогена. При этом севернее Самарской Луки Волга протекала в центральной части Мелекесской впадины, а южнее направлялась на югозапад и протекала в районе Чапаевска, направляясь далее по оси Вольской мульды, обходя с северо-запада Пугачевскую дислокацию. Приволжская возвышенность испытала мощное поднятие, которое к нижнему плиоцену сменилось опусканием, приведшим позднее к трансгрессии Акчагыльского моря.

Заметим, что к плиоцену уже установилась ясная зональность растительного покрова не только на Русской равнине, но и во всем северном полушарии [13, 14, 15]. Мнение Ю.Д. Клеопова [16, с. 189] о том, что 
«равнинная умеренная зона Евразии в неогене имела однообразный характер растительности типа мезофильных широколиственных (с примесью более древних хвойных пород) лесов. Другие типы растительности (степной ... и т.д.) развивались в это время в других центрах: сухих нагорьях, расчлененных горных системах, приполярных районах» не согласуется с предположением И.И. Спрыгина [17, с. 307-308), который допускал для Среднего Поволжья, что «...в конце плиоцена существовали фитоценозы, принадлежащие к главнейшим группам, на которые расчленяется современный растительный покров лесной и степной зон Евразии, а именно фитоценозы из группы широколиственных лесов, из группы хвойных (во главе с сосной и елью) и группа степных фитоценозов». Мнение И.И. Спрыгина о разнообразном характере растительности Поволжья, сформировавшимся к концу плиоцена, подтверждено последующими исследователями $[2,8,13]$.

О становлении основных растительных формаций, произрастающих в регионе в течение плиоцена, имеются следующие воззрения. Формирование сосновых лесов на Приволжской возвышенности, близких по своему характеру к современным, В.В. Благовещенский [3] относит к верхнему плиоцену, а уникальных формаций разреженных сосновых лесов на каменистых субстратах (схожих с горными сосняками в понимании Д.И. Литвинова, но не идентичных им, поскольку формирование степного разнотравья в них началось позднее - прим. авторов) - к началу миоцена. Появление хвойных лесов типа тайги также относится к плиоцену [18]. Лиственные леса северного полушария, согласно А.Н. Криштофовичу [19], явились продуктом преобразования тургайской флоры. Из Азии же происходил процесс продвижения травянистых равнин, сформировавшихся на основе существования засушливых областей еще в мезозое. Первые достоверные сведения палинологического характера о наличии травянистой растительности на юге и юго-востоке Русской равнины относятся к верхнему миоцену - нижнему плиоцену [14]. Формирование зоны настоящих степей в Предуралье В.К. Немкова [15] относит к границе миоцена и плиоцена. В.В. Благовещенский [3] полагает, что степные элементы флоры стали проникать на Приволжскую возвышенность в конце миоцена. Существование еще одного типа сообществ на сухих каменистых склонах гор на Урале - своеобразных сообществ травянистых растений-ксерофитов, предшественников современных петрофитных степей, П.Л. Горчаковский [20] допускает уже в плиоцене. По его мнению, с этими сообществами связано происхождение большинства скальных и горно-степных эндемиков Урала.

Климат к началу плиоцена характеризовался как прохладный, средняя температура января составляла -8 $--10^{\circ} \mathrm{C}$, июля $-+17-+20^{\circ} \mathrm{C}$, среднегодовая до $+7^{\circ} \mathrm{C}$, a количество осадков 650 мм в год $[12,21]$.

В Среднем Поволжье в это время произрастали темнохвойные еловые леса таежного типа с участием сосен, пихты, тсуги и смешанные леса с участием березы, вяза, дуба и сосны [22], тогда как южнее основным типом ландшафта были степи с монодоминантными фитоценозами из маревых, существовавшие здесь с мэотиса [8, 12].

Для Приволжской возвышенности отмечается появление в составе плиоценовых отложений пыльцы рас- тений степных формаций (Chenopodiaceae, Artemisia, Polygonaceae), что, однако, происходило на фоне почти абсолютного доминирования на большей территории комплексов лесного типа с преобладанием представителей Pinus [24]. На доминирование в это время в Поволжье светлых сосновых лесов с подлеском из вечнозеленых кустарничков свидетельствует также Е.Н. Ананова [3]. Травы преобладали (44-57\%) только в долинах рек, в то время когда на долю древесных форм и споровых здесь приходилось 21-35 и 12-14\% соответственно [24]. Заметим, что при реконструкции растительного покрова по палинологическим данным сложнейшую проблему представляет определение автохтонности спор и пыльцы в спектре. Так, дальность ветрового заноса пыльцы сосны может превышать 1500 км, в то время как дуба - не более 1 км. Доля древесной заносной пыльцы в спектрах из травяных сообществ может достигать 50\%. Пыльца многих листопадных деревьев и травянистых растений, напротив, имеет тенденцию отлагаться локально [23].

В нижнем плиоцене в Поволжье преобладали континентальные условия. Температуры, определенные по методу В.П. Гричука, колебались в январе от -3 до -8 ${ }^{\circ} \mathrm{C}$, а в июле не опускались ниже $+19{ }^{\circ} \mathrm{C}$. К концу раннего плиоцена произошло потепление климата [8].

На суше, которая дренировалась палеореками, доминировали лесные и лесостепные пространства. В составе доминировавших в это время еловых лесов с лиственницей и темнохвойными соснами, возросло участие тсуги и широколиственных пород (вяз, дуб, бук, орех, лапина, липа, ясень, граб, лещина, возможно, ликвидамбар и нисса). Береза и ольха, входившие в состав елового леса в качестве примеси, местами образуя самостоятельные формации. Из других мелколиственных пород встречались ивы, из вечнозеленых - падуб, сумах, входившие в состав подлеска. Богато был представлен травянистый покров. В дальнейшем теплые и влажные условия начала челнинского времени сменились умеренно-теплыми, а затем и более сухими. В лесах на смену влаголюбивым елям пришли сосны. Снизилась доля участия в составе леса широколиственных пород, среди которых преобладали дуб и орешник [8, $11,22]$. В заволжской части Нижнего Поволжья в это время преобладали травянистые растения (Chenopodiaceae, Convolvulaceae, Artemisia), тогда как на долю древесных (Pinus, Picea, Abies, Tilia, Tsuga) и кустарниковых пород приходится значительно меньшая доля в составе фитоценозов [28].

В плиоценовых отложениях на Каме П.И. Дорофеевым обнаружены остатки Picea, Tsuga, Pinus, Larix, Betula, Alnus, Morus, Stephanandra, Weigela, Cornus, Sambucus, Daphne, Actinidia и многих травянистых растений, среди которых еще сохранились Azolla pseudopinnata, Salvinia tuberculata, Nafas foveolata, Caldesia и др. [19]. Такой состав лесов, в которых изредка встречались еще Pterocarya, Fagus, Castanea, Ulmus, Zelcova, Celtix, Ilex, Ericaceae, указан А.А. Чигуряевой с соавторами [25] для всего юго-востока Европейской России.

В.К. Немкова отмечает, что в начале плиоцена на юге Предуралья большая часть древесных пород и кустарников была представлена современными или очень близкими к ним видами, а значительное количество доплиоценовых реликтов сохранялось, главным образом, в водно-болотных биоценозах [15]. При этом, в 
отличие от современных моно- и олигодоминантных таежных лесов европейской части России и Сибири, неогеновые леса были полидоминантными [9] и более разнообразными по видовому составу.

В среднем плиоцене береговая линия морского бассейна достигла южных отрогов возвышенности Общего Сырта. Растительный покров этого времени формировался при относительно прохладном климате с отчетливо выраженными сезонами. Самым холодным месяцем был январь, с изменением температур от +1 до $8^{\circ} \mathrm{C}$ [8]. По другим данным [12], в начале акчагыла январские температуры понижались до $+1 \ldots+2^{\circ} \mathrm{C}$, июльские превышали $+14 \ldots+21^{\circ} \mathrm{C}$, среднегодовые до +4 $8^{\circ} \mathrm{C}$. Начало сокольского времени было умеренно-теплым и достаточно сухим, а конец - более влажным. Максимально теплым периодом была середина сокольского времени [9].

В начале сокольского времени елово-сосновые и светлохвойные сосновые леса продолжали доминировать на территории Среднего Поволжья. Площадь темнохвойных лесов в виду сухости климата сократилась. Под пологом сосновых лесов в местах с наиболее богатыми почвами появились единичные широколиственные породы - вяз, клен, орех, бук. В середине сокольского времени широкое распространение по территории получили широколиственно-сосново-еловые леса. Состав широколиственных пород в это время становится разнообразнее и они образуют отдельные формации смешанных лесов: из широколиственных это бук, вяз, дуб, орех, липа (Л.И. Линкина указывает, что из всех широколиственных формаций именно липовые были наиболее распространенными [9]), клен, нисса. В сложении леса возросла доля участия ели и тсуги. Ельники занимали наиболее увлажненные места. В конце сокольского времени участие в составе лесов широколиственных пород и тсуги снизилось. Для этого времени характерно распространение сосново-еловых лесов, из широколиственных пород остается только липа $[9,22]$.

Для Южного Урала в это время констатируется заметное сокращение общего числа видов и исчезновение почти всех доплиоценовых реликтов и многих собственно плиоценовых видов. Также, в связи с широким распространением таежных лесов, отмечено значительное сокращение числа видов травянистых растений. В это же время в регионе впервые отмечается появление растений горных тундр, таких как Lycopodium pungens L. [15].

П.И. Дорофеев указывает на связь плиоценовых таёжных сообществ с горными условиями: «...хотя и в это время они (темнохвойные леса - прим. авторов), по-видимому, всё ещё тяготеют к горным странам, например к Уралу, так как в Башкирии, Татарии и даже в районе Самарской Луки их остатки встречаются чаще и более обильны, чем в западных областях, начиная от Воронежа» [26], а М.В. Шустов связывает с ними появление бореальных реликтов лихенофлоры на Приволжской возвышенности [27].

Установившиеся на территории в конце сокольского времени умеренно-теплые и влажные условия к началу чистопольского времени сменились более сухими. На исследуемой территории вновь начали господствовать елово-сосновые леса. Последующее увеличение влажности привело к развитию еловых и сос- ново-еловых лесов. На отдельных участках леса, особенно по понижениям, где было достаточно влажно, произрастали тсуга и широколиственные породы (липа, дуб, вяз, граб, лапина, гикори, бук, клен, орех, нисса и орешник). Однако вскоре установился сухой климатический режим и доминирующей породой стала сосна. Участие ели, тсуги, пихты, а также березы и ольхи снижается. Широколиственные породы практически исчезли из состава леса [9].

В среднем акчагыле для юга Предуралья [15] отмечается незначительное разнообразие видов основных лесообразующих пород с абсолютным преобладанием современных видов при наличии единичных реликтов и собственно плиоценовых форм. С увеличением сухости здесь распространились степные пространства с небольшими по площади березовыми и широколиственными лесами и только на самом юге, где пониженные участки были затоплены водами начинающейся ингрессии, на возвышенностях росли сосновые леса с елями, тсугами и широколиственными породами. Позднее таежные леса сменились ксерофитными степями и небольшими по площади березово-широколиственными лесами (дубы, липы, вязы, граб и ясень).

В Нижнем Поволжье на сохранившихся участках суши были распространены различные растительные формации, относящиеся к лесному (елово-тсуговому, сосново-еловому), лесостепному (елово-сосново-лиственно-полынно-маревому, сосново-ольхово-марево-полынному), степному или полупустынному (сосновополынно-маревому, марево-полынному) типам. Для всей изучаемой территории в целом наиболее характерны Pinus subgen. Diploxylon, Picea, Abies, Tsuga, Ephedra, Betula, Carpinus, Alnus, Corylus, Ulmus, Quercus, Acer, Tilia, Chenopodiaceae, Artemisia, Poaceae, Apiaceae, Asteraceae, Potamogeton, Typha, Nymphaeaceaе и др. Дальнейшее изменение растительности можно охарактеризовать как постепенное остепнение, когда к середине акчагыла на долю травянистых растений приходилось уже около 30\%. Затем в верхнеакчагыльских слоях содержание пыльцы древесных, травянистых и споровых (сфагнового мха и папоротников) растений выравнивается [28].

Начиная с этого времени выявлена четкая ритмичность в смене соотношения площадей, занятых различными формациями, тогда как в составе формаций больших изменений не наблюдается [22].

В конце чистопольского времени соленые воды трансгрессирующего морского бассейна (в период максимальной трансгрессии солевой режим бассейна был, вероятно, выше, чем в современном Каспийском море) устремились на север, затопили огромные пространства, ингрессировали в развитые долины существовавшего эрозионного рельефа и распространились до района Казани по Волге и до верховий Камы и Белой. Трансгрессия развивалась очень стремительно, высокий рельеф побережий не успевал разрушаться, поэтому морские воды проникли вглубь континента только по речным долинам, образуя многочисленные заливы типа эстуариев, значительно сократив площади денудационных равнин $[2,8]$.

В это время Самарская Лука представляла собой узкий полуостров, изрезанный узкими заливами и бухтами. В ее районе залив Акчагыльского моря сильно сужался, морские воды проникали на север через узкий 
пролив Жигулевских ворот и к северу залив расширялся вновь [2]. Приволжская возвышенность была затоплена у Сызрани ориентировочно до горизонтали 100 м (есть отложения близ с. Новая Рачейка).

Островом возвышалась возвышенность Общего Сырта [8], которая была затоплена в исследуемом регионе лишь частично, приблизительно по линии Заплавное - Алексеевка - Бол. Глушица (см. [29]). На северо-востоке Заволжья Акчагыльское море было распространено до Сергиевска (шиханный рельеф, повидимому, был островами, однако в его формирование немалую лепту внесла и неотектоника - например, купола на Сокско-Иржинском междуречье и близ верховий Шунгута появились позже).

Климатические изменения этого времени связаны с развитием акчагыльской трансгрессии. В течение всего периода прогрессировало похолодание климата с увеличением контрастности зимних и летних температур, сопровождавшееся периодичностью эпох более теплого и холодного климата. Эпохи похолодания отличались более низкими температурами и большей продолжительностью, по сравнению с теплыми эпохами [12]. Ритмичность климатической обстановки (каждый ритм состоял из двух чередующихся фаз: первой теплой и влажной и второй - умеренно-теплой и/или влажной или сухой) нарушается вторжением на территорию Среднего Поволжья вод акчагыльской трансгрессии [9].

В начале акчагыльской трансгрессии климат был умеренно теплым, с тенденцией к похолоданию вплоть до максимально низких температурных значений января за весь плиоцен $-14--16^{\circ} \mathrm{C}$, среднеиюльские температуры составляли $+12-+14{ }^{\circ} \mathrm{C}$, а среднегодовое количество осадков составляло 550-600 мм $[8,21]$. В среднем и позднем акчагыле среднегодовые температуры достигли минимальных значений и составляли всего $+2^{\circ} \mathrm{C}[12]$.

В начале периода, когда климат был относительно теплым и влажным, на территории были распространены смешанные хвойно-широколиственные с доминированием ели и сосна и, в меньшей степени, пихты и тсуги, и широколиственные леса, состоящие в основном из липы, дуба, вяза и орешника [9]. На Нижней Каме для этого времени отмечены 3 вида тсуги, 2 вида дуба (в т.ч. один - вечнозеленый), 3 вида вяза, 2 вида дзельквы, 3 вида клена, орех, лапина, граб, липа, ясень, 5 видов тополя, лещина, 3 вида березы, 7 видов ивы, ольха, восковник, рябина, черемуха, крушина. В водоемах, вероятно, встречались альдрованда, дулииум, азолла, декодон, наяда, трапа, эуриала. Окружали водоемы разные виды ольхи, ивы [22].

Вторжение на территорию Среднего Поволжья вод акчагыльской трансгрессии привело к похолоданию и увеличению влажности. Из состава флоры выпадали наиболее теплолюбивые растения. Широкое распространение в это время получили хвойные леса - вначале темнохвойные пихтово-еловые, позже сосновые. Роль сосны, пихты и особенно лиственных пород была незначительной $[9,22]$. Согласно В.Н. Староверову [8], во время самой холодной эпохи в плиоцене на юговостоке Русской плиты распространились леса таежного типа, в которых максимального распространения достигли тсуги и полностью отсутствовали широколиственные деревья.
Вероятно, к этому периоду относится указание В.П. Гричука (1950), который, ссылаясь на П.А. Никитина, обнаружившего в верхнеплиоценовых отложениях под Сызранью остатки таежной флоры, полагает, что хвойные леса в бассейне Волги спускались южнее Самарской Луки. В то же время в отложениях Самарской Луки П.И. Дорофеевым обнаружены остатки Pinus, Picea, Tsuga, Cornus, Sambucus, Staphylea в сопровождении множества травянистых растений [19]. Таежные леса в этот период достигли максимального распространения и не только охватывали территорию Приволжской возвышенности, но спускались к югу от отрогов Общего Сырта [3].

На Южном Урале преобладающим типом растительности вновь становятся хвойные леса, вытесненные позднее лесостепными ландшафтами в конце среднеакчагыльского времени, когда климат стал даже теплее современного [15]. Потепление климата в это время для южной части Общего Сырта было отмечено А.А. Чигуряевой с соавторами [25].

Морской режим закончился к концу плиоцена, когда начался новый подъем суши. На территории Заволжья осушению в первую очередь подверглись прибрежно-мелководные участки на севере Саратовского Заволжья и в зоне сочленения низких водораздельных пространств Самарского Левобережья с возвышенностью Общего Сырта. Континентальные обстановки, окружавшие полуморской бассейн, в геоморфологическом отношении представляли денудационную равнину. Море мелело, постепенно опреснялось и отступало, оставляя проточные и полупроточные пресноводные озера на месте ингрессионных заливов $[2,8]$.

После отступления вод акчагыльского бассейна с территории Среднего Поволжья климат, оставаясь прохладным, стал более сухим. В.Н. Староверов для позднего акчагыла указывает на колебание температур от $-10--12^{\circ} \mathrm{C}$ в январе до $+15-+17^{\circ} \mathrm{C}$ в июле [8].

В начале регрессии акчагыльских вод наблюдалась кратковременная фаза изреживания таежных лесов, на смену которым пришли березовые и травянистые формации. Роль хвойных пород - ели и сосны значительно снизилась. По понижениям местами сохранились отдельные экземпляры дуба, вяза и орешника. Открытые пространства были заняты полынно-маревыми и разнотравными ассоциациями [9, 22].

Данные спорово-пыльцевого анализа образцов, взятых в Ширяевской и Аскульской долинах, а также в пойме Волги у Липовой Поляны (соврем. пос. Богатырь) [2] показали присутствие пыльцы хвойных, относящихся к родам Picea и Pinus, морфологически отличная от пыльцы современных Picea excelsa Link. и Pinus silvestris L. Также была встречена пыльца полыни и лебедовых. Общий облик Самарской Луки был, вероятно, лесной, причем в составе леса имелись как хвойные (ель, сосна, пихта), так и лиственные (ива, орешник, особенно много березы и ольхи) породы. Из травянистой растительности были распространены полыни и лебедовые. Для травянистого покрова Заволжья указываются вересковые и сфагновые растения [8]. Таким образом, к концу плиоцена остаются наиболее холодоустойчивые роды, относящиеся к евроазиатскому (панголарктическому) и отчасти американо-евроазиатскому географическим элементам [9]. Для юга Предуралья в конце плиоцена отмечены последние находки пыльцы тсуги [15]. 
Заключение. Таким образом, плиоцен - очень неспокойный геологический век, во время которого относительно быстро происходила смена теплых и холодных этапов, каждый из которых характеризовался ландшафтно-климатическими изменениями. Преобразования ландшафтной обстановки происходили на фоне прогрессирующего похолодания климата с увеличением контрастности летних и зимних температур. Основные геоморфологические структуры Среднего Поволжья, такие как Приволжская возвышенность, Сaмарская Лука, Жигулевские горы, Общий Сырт, речная сеть, возникли или до начала этого периода, или в течение него. Основные растительные формации в их широком понимании (тайга, широколиственные и мелколиственные леса, степи) сложились уже к началу плиоцена. В плиоцене происходило лишь их обеднение за счет постепенного исчезновения теплолюбивых видов и приближение по составу к современным формациям. Большая часть видов к концу плиоцена приняли современный облик.

\section{СПИСОК ЛИТЕРАТУРЫ:}

1. Зозулин Г.М. Исторические свиты растительности // Ботанический журнал. 1970. Т. 55, № 1. С. 23-33.

2. Обедиентова Г.В Происхождение Жигулевской возвышенности и развитие ее рельефа // Материалы по геоморфологии и палеогеографии СССР. Т. 8. Тр. Инта географии. М.: Изд-во АН СССР, 1953. 248 с.

3. Благовещенский В.В. Растительность Приволжской возвышенности в связи с ее историей и рациональным использованием. Ульяновск: УлГУ, 2005. 715 с.

4. Гладенков Ю.Б. Неогеновая система Международной стратиграфической шкалы и региональные схемы неогена России // Общая стратиграфическая шкала России: состояние и перспективы обустройства: Всерос. конф. Сб. ст. М.: ГИН РАН, 2013. С. 341-350.

5. Гладенков Ю.Б. Громкая стратиграфическая дискуссия начала XXI века (статус и нижняя граница квартера) // Стратиграфия. Геологическая корреляция. 2010. T. 8, № 2. C. $125-128$.

6. Объяснительная записка к унифицированной региональной стратиграфической схеме неогеновых отложений Южных регионов Европейской части России / JI.А. Невесская, Е.И. Коваленко, Е.В. Белуженко и др. М.: ПИН РАН, 2004. 83 c.

7. Данукалова Г.А. Стратиграфическое подразделение неогеновых отложений Южно-Уральского региона // Мат. VIII Межрег. геол. конф. Уфа, 2010. С. 39-41.

8. Староверов В.Н. Фациальные модели и палеогеография юго-востока Русской плиты в плиоцене: автореф. ... докт. геол.-минерал. наук. Воронеж, 2005. 35 с.

9. Линкина Л.И. Палинокомплексы неогеновых отложений центральной части Среднего Поволжья: автореф. дис. ... канд. геол.-минер. наук. Казань, 2007. 24 с.

10. Петрова Е.В., Линкина Л.И. О положении биклянского и омарского горизонтов в разрезах неогенчетвертичных отложениях Среднего Поволжья // Учен.зап. Казанского ун-та. Сер. Естеств. науки. 2012. Т. 154, кн. 3. С. 186-195.

11. Линкина Л.И., Петрова Е.В. Климатические и ландшафтные условия Среднего Поволжья на рубеже миоцена и плиоцена // Учен. зап. Казан. ун-та. Сер. Естеств. науки. 2015. Т. 157, кн. 1. С. 34-48.

12. Изменение ландшафтов и климата за последние 65 млн. лет (кайнозой: от палеоцена до голоцена) / Под ред. проф. А.А. Величко. М.: ГЕОС, 1999. 260 с.
13. Криштофович А.Н. Развитие ботанико-географических провинций северного полушария с конца мелового периода // Советская ботаника. 1936. № 3. С. 9 24.

14. Ананова Е.Н. О флоре и растительности Русской равнины в плиоцене (по палинологическим данным) // Докл. сов. палинологов в I междунар, палинолог. конфер. (Таксон, США). М.: Изд-во АН СССР, 1962. C. $137-144$.

15. Немкова В.К. Флоры и растительность Предуралья в плиоцене, плейстоцене и голоцене // Флора и фауна кайнозоя Предуралья и некоторые аспекты магнитостратиграфии. Башкир. НЦ УрО РАН, 1992. С. 11-32.

16. Клеопов Ю.Д. Основные черты развития флоры широколиственных лесов Европейской части СССР // Материалы по истории флоры и растительности СССР, вып. 1. М.; Л.: АН СССР, 1941. С. 183-256.

17. Спрыгин И.И. Реликтовые растения Поволжья // Материалы по истории флоры и растительности СССР, вып. 1. М.; Л.: АН СССР, 1941. С. 293-314.

18. Толмачев А.И. К истории возникновения и развития темнохвойной тайги. М.; Л.: Изд-во АН СССР, 1954. $155 \mathrm{c}$

19. Криштофович А.Н. Палеоботаника. Л.: Гостоптехиздат, 1957. $650 \mathrm{c.}$

20. Горчаковский П.Л. Растения европейских широколиственных лесов на восточном пределе ареала. Свердловск, 1968. 207 с.

21. Ятайкин Л.М., Шаландина В.Т. История растительного покрова в районе Нижней Камы с третичного времени до современности. Казань: Изд-во Казанск. Ун-та, 1975. $198 \mathrm{c}$.

22. Николаева К.В. История растительности Среднего Поволжья в плиоцене // Самарская Лука. Бюллетень. 1993. № 4. С. 76-83.

23. Курманов Р.Г., Ишбирдин А.Р. Палинология: уч. пос. // Уфа: РИЦ БашГУ, 2012. 92 с.

24. Иосифова Ю.И., Грищенко М.Н., Красненков Р.В. Северная часть Центральных районов Восточно-Европейской платформы // Стратиграфия СССР. Неогеновая система. М.: Недра, 1986. Полутом 1. С. 308-331.

25. Чигуряева А.А., Скиданова Е.А., Яхимович В.Л. Материалы к истории растительности юго-востока европейской части СССР в среднеплейстоценовое время // Вопросы геологии восточной окраины Русской платформы и Южного Урала. Уфа, 1960. Вып. 5. С. 109-128.

26. Дорофеев П.И. Третичные флоры Урала. Л.: Наука, 1970. 67 с.

27. Шустов М.В. Реликты лихенофлоры Приволжской возвышенности // Фиторазнообразие Восточной Европы. 2007. № 4. С. 3-25.

28. Завьялов Е.В., Шляхтин Г.В., Т Табачишин В.Г., Макаров В.З., Березуцкий М.А., Якушев Н.Н. Генезис природных условий и основные направления современной динамики ареалов животных на севере Нижнего Поволжья. Сообщение II. Генезис фауны и флоры в третичное время. Неоген // Поволжский экологический журнал. 2002. № 2. С. 91-107.

29. Палеогеография. 2014. Энциклопедия Самарской области. [Электронный ресурс]. URL: https://sites. google.com/site/ievbmuseum/home/enciklopediasamarskoj-oblasti/geologia/obsaa/paleogeografia.

Статья публикуется при поддержке гранта РФФИ (проект р_поволюжье № 14-04-97072) 


\title{
GEOGRAPHICAL CONDITIONS AND EVOLUTION OF VEGETATION COVER OF MIDDLE VOLGA REGION IN THE PLIOCENE
}

(C) 2016
S.A. Senator, candidate of biological sciences, senior researcher of the Laboratory of Problems of Phytodiversity
V.P. Morov, researcher of Ecological Museum
Institute of Ecology of the Volga river Basin of Russian Academy of Science, Togliatti (Russia)

\begin{abstract}
The development of flora on the territory of the Middle Volga region during the Pliocene is discussed. An attempt to reconstruct geographic conditions and vegetation cover is taken. A short description of the natural environment and landscape, of the vegetation cover of the Middle Volga and adjacent territories is done. The comparative scheme of the total and the regional scales of Pliocene is added. In the given paper one assumes the upper boundary of the Pliocene to be the upper boundary of the Gelasian Stage. The Pliocene is rather turbulent geological period during there was a relatively quick change of warm and cold phases, each of which is characterized by landscape and climate change. Landscape transformations took place against a background of progressive climate cooling with an increase in the contrast of summer and winter temperatures. Main geomorphological structures of the Middle Volga region, such as the Volga Upland, Samara Bend, Zhiguli Mountains, Obshhij Syrt, river network, appeared prior or during this period. Main plant formations in their broadest sense (taiga, broad-leaved and small-leaved forests, steppes) had already been formed by the beginning of the Pliocene. During the Pliocene period the depletion of those plant formations took place. It occurred due to the gradual extinction of thermophilic species and bringing in their composition to modern formations. Most of the species had taken modern form by the end of the Pliocene.

Keywords: Pliocene, geographical conditions, climate, vegetation cover, reconstruction, the Middle Volga region, Volga, the Volga Upland, Zavolzh'e, Obshhij Syrt, Akchagyl'skoe sea, akchagyl, chelninskaya suite, sokol'skaya suite, chistopol'skaya suite, domashkinskaya suite.
\end{abstract}

УДК 504.064.36:631.461

\section{МИКРОБИОЛОГИЧЕСКИЙ МОНИТОРИНГ АНТРОПОГЕННО ПРЕОБРАЗОВАННЫХ ПОЧВ}

(C) 2016

E.B. Симонова, доктор биологических наук, профессор кафедры микробиологии, вирусологии и иммунологии Иркутский государственный медищинский университет, Иркутск (Россия)

Е.Н. Максимова, кандидат биологических наук, доцент кафедры естественнонаучных дисциплин Педагогический институт Иркутского государственного университета, Иркутск (Россия)

Аннотация. В статье приводятся результаты микробиологического мониторинга искусственных почв, которые сформировались в процессе рекультивации шлам-лигнина в картах-накопителях Байкальского целлюлознобумажного комбината (Иркутская область). Исследуемые карты относятся к Солзанскому полигону, расположенному между пос. Солзан и р. Большая Осиновка к югу от автотрассы Иркутск - Улан-Удэ. Обследованы картынакопители № 1, № 4, № 5, № 6, где пробы грунта отобраны в трех горизонтах (поверхностный, средний и придонный) в одной усредненной точке. Оценка шлам-лигнина проведена согласно общепринятым санитарномикробиологическим методам исследования почв, с применением интегрального показателя - ОМЧ/г почвы. Показана доля участия в микробиоценозе аэробов, анаэробов, бактерий и грибов. Степень обсемененности почвы указывает на сильную степень загрязнения. Соотношение прокариотической микрофлоры к эукариотической в среднем составляет 3:1. Это говорит о значительной роли в биодеструкции лигнина бактериальных форм. Превалирование, аэробов над анаэробами, дает основание утверждать, что в глубинных слоях шлам-лигнина биодеструкция идет крайне медленно. Полученные данные показывают, что методы микробиологического мониторинга относятся к экспрессным методам анализа и дают комплексную оценку экологического состояния почвы.

Ключевые слова: шлам-лигнин, общее микробное число, микробиоценоз, степень загрязнения, аэробы, анаэробы, прокариоты, эукариоты, бактерии, грибы, биодеструкция, техногенные загрязнители, рекультивация, микрофлора, санитарно-микробиологическое состояние, мониторинг, целлюлозно-бумажный комбинат

Устойчивость почв к широкому спектру техногенных загрязнителей определяется многими факторами (гранулометрический состав, структурное состояние, pH среды, буферность и т.д.), поэтому существующие методы и приемы мониторинга почв отличаются большим разнообразием [1-4]. При этом состояние почв традиционно оценивается как по физическим и химическим, так и биологическим показателям, среди которых альгологические, бактериологические и др. [5-12].

Техногенные загрязнители подвергаются в почве разнообразным и многоступенчатым процессам биологической трансформации с участием микроорганизмов.

При этом одни химические соединения легко разрушаются, другие, например, лигнин, поступающий в природные экосистемы при естественной гибели растений в очень больших количествах, является главным источником медленно распадающегося органического вещества [13]. Но наиболее опасным является лигнин, загрязняющий окружающую среду как бытовой отход, предприятий целлюлозно-бумажной промышленности.

Мероприятия по мониторингу территории, загрязненной захороненными в ней промышленными отходами, кроме прочих включают проведение санитарномикробиологических исследований, целью которых яв- 